\title{
Analysis of intra-country virtual water trade strategy to alleviate water scarcity in Iran
}

\author{
M. Faramarzi ${ }^{1,2}$, H. Yang ${ }^{2}$, J. Mousavi ${ }^{3}$, R. Schulin ${ }^{4}$, C. R. Binder ${ }^{5}$, and K. C. Abbaspour ${ }^{2}$ \\ ${ }^{1}$ Departement of Natural Resources, Isfahan University of Technology, 84156 Isfahan, Iran \\ ${ }^{2}$ Eawag, Swiss Federal Institute of Aquatic Science and Technology, P.O. Box 611, 8600 Dübendorf, Switzerland \\ ${ }^{3}$ Deptartement of Civil Engineering, Amirkabir University of Technology, Tehran, Iran \\ ${ }^{4}$ Institute of Terrestrial Ecosystem, ETH Zürich, Universitätstr. 16, 8092 Zürich, Switzerland \\ ${ }^{5}$ Institute for System Science, Innovation and Sustainability Research, University of Graz, Merangasse 18/I, 8010 Graz, \\ Austria
}

Received: 4 April 2010 - Published in Hydrol. Earth Syst. Sci. Discuss.: 28 April 2010

Revised: 13 July 2010 - Accepted: 17 July 2010 - Published: 2 August 2010

\begin{abstract}
Increasing water scarcity has posed a major constraint to sustain food production in many parts of the world. To study the situation at the regional level, we took Iran as an example and analyzed how an intra-country "virtual water trade strategy" (VWTS) may help improve cereal production as well as alleviate the water scarcity problem. This strategy calls, in part, for the adjustment of the structure of cropping pattern (ASCP) and interregional food trade where crop yield and crop water productivity as well as local economic and social conditions are taken into account. We constructed a systematic framework to assess ASCP at the provincial level under various driving forces and constraints. A mixedinteger, multi-objective, linear optimization model was developed and solved by linear programming. Data from 19902004 were used to account for yearly fluctuations of water availability and food production. Five scenarios were designed aimed at maximizing the national cereal production while meeting certain levels of wheat self-sufficiency under various water and land constraints in individual provinces. The results show that under the baseline scenario, which assumes a continuation of the existing water use and food policy at the national level, some ASCP scenarios could produce more wheat with less water. Based on different scenarios in ASCP, we calculated that $31 \%$ to $100 \%$ of the total wheat shortage in the deficit provinces could be supplied by the wheat surplus provinces. As a result, wheat deficit provinces would receive 3.5 billion $\mathrm{m}^{3}$ to 5.5 billion $\mathrm{m}^{3}$ of virtual water by importing wheat from surplus provinces.
\end{abstract}

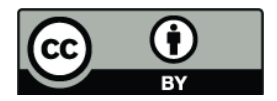

Correspondence to: K. C. Abbaspour (abbaspour@eawag.ch)

\section{Introduction}

Population growth and industrialization on the one hand and extended drought, environmental concerns, and a possible adverse impact of climate change on the other hand are the major limiting factors on water resources threatening food security in developing countries of arid and semi-arid regions. With no significant room to expand cultivation areas in these regions, increased food demand will have to be met through sustainable agricultural production, which entails improved management of the available resources and development of crop production strategies (Qadir et al., 2007) as well as import from outside (Yang et al., 2006; Allan, 1997).

Large parts of Iran are characterized as arid and semiarid environment. The country is enduring increasing water scarcity, which has posed a major constraint to the expansion of crop land and food production. Agriculture is by far the largest water user in Iran, accounting for more than $90 \%$ of the total water withdrawal. Despite the scarce water resources, wheat self-sufficiency has long been an important national goal, which was temporarily achieved in 2004. However, there is a general doubt about Iran's ability to maintain this level of production amid the mounting water challenges, among other obstacles. In general, the agricultural water use efficiency is low in Iran. The average irrigation and conveyance efficiency is around $36 \%$ at the national level. For many provinces, the efficiency can be as low as $15 \%$. Main reasons for low efficiency are improper design of irrigation facilities, poor maintenance, careless operation, negligible water pricing, as well as inefficient division of responsibilities among different agencies (Pazira et al., 1999; Kehsavarz et al., 2005). Efforts to increase the

Published by Copernicus Publications on behalf of the European Geosciences Union. 
agricultural water use efficiency have been made through increasing crop water productivity (CWP) at plant and field levels (Ardakanian, 2005). But this has not so far alleviated the water scarcity problem, as in many areas the situation has been worsening.

Facing the sober challenges, there have been renewed calls and efforts from the government of Iran to improve water resources management and plans to mitigate water scarcity. The long term policies are to invest on water projects, exploit new water resources, and investigate the benefits from adjustment of structure of cropping pattern (ASCP) to deal with the growing water shortages (National Research Council, NRC, 2005; The 5th World Water Forum by Iranian Ministry of Energy, 2009). So far, however, bulk of the investment is allocated for harnessing and regulating water resources via construction of dams, water transfer projects, and building irrigation networks (http: //icerik.worldwaterforum5.org/files/ThematicDocuments/ SessionDocuments/18_03_2009/Ayvansaray/). Little effort has so far been made in developing a strategy for ASCP.

Iran currently has 19 million ha of agricultural land, accounting for $12 \%$ of the total area of the country. Of the total agricultural land, over $60 \%$ is devoted to wheat, $20 \%$ to barley, $5 \%$ to rice, $2 \%$ to maize and the rest of the land is covered by other crops. Cereals are the largest user of irrigation water. Of the total water diverted to irrigate cereal crops, wheat uses more than $70 \%$. This amount of water exceeds the internal renewable blue water resources (IRWR) in many provinces located in central dry regions. Therefore, a large amount of water is extracted from fossil groundwater or water transfer projects to meet the water demand. It was found by Faramarzi et al. (2009) that about $53 \%$ of the area under cultivation of wheat in Iran is located in water scarce sub-basins. Of the total wheat production (10.83 million tons) in the country, 4.4 million tons of irrigated wheat and 1.9 million tons of rainfed wheat are produced every year in water scarce regions. This has a significant implication for future agricultural food production.

The virtual water trade (VWT) introduced by Allan (1997) has been seen as one of the ways to improve water use efficiency and to mitigate water scarcity at the regional level through ASCP and interregional food trade (Chapagain et al., 2006; Yang et al., 2006; Liu and Savenije, 2008; Liu et al., 2007). What we refer to as "virtual water trade strategy" (VWTS) in this paper involves adjustment of the structure of cropping pattern and interregional food trade where crop yield $(y)$ and CWP, national food production objectives, as well as local economic and social conditions are taken into account as discussed in Sect. 2.2.

VWT has so far been mainly studied in the arena of international trade. A set back in developing a clear VWTS internationally has been the exercise of trade sanctions imposed on importing countries at will. This although did not stop VWT, it had the effect of deterring the countries from formulating clear and long-term VWT strategies as an ef- fective policy option for combating local water scarcities. The principles of VWT are also applicable within a country like Iran where there are lesser political barriers in interprovincial trades and significant regional variations in climate, resources and crop production. In such a situation, water resources can be used more efficiently at the national level if crops are produced in the regions/provinces where CWP is large and exported to the regions where CWP is small. However, any change in cropping structure is subject to many factors ranging from natural resources, ecological, socio-economic, and institutional conditions. Hence, there is a need for a systematic framework to support the policy makers in the planning of the structure of regional cropping pattern to meet certain national goals of food production while taking these constraints into consideration. Based on the best of our knowledge, so far such a study has not been seen in the virtual water literature. The current study is a novel step to develop a systematic framework for implementing VWTS in Iran through ASCP.

Improving the water resources management through ASCP can be formulated as a multi-criteria analysis problem and solved by optimization methods. In the literature there are different techniques dealing with multi-criteria analysis problems. Very broadly they can be grouped into two categories: participatory based decision making processes and non-participatory based optimization techniques. The first category includes methods such as: multiple-criteria utility functions (e.g. Prato and Herath, 2007), analytical hierarchy process (AHP) (e.g. Mau-Crimmins et al., 2005), and Electre (e.g. Kangas et al., 2002; Figueria and Roy, 2002). In the second category, the techniques of linear programming (Makowski et al., 2000), genetic algorithms (Ines et al., 2006), meta modeling (Mousavi and Shourian, 2010), and goal programming (Foued and Sameh, 2001; Agha, 2006; Al-Zahrani and Ahmad, 2004; Yang and Abbaspour, 2007) are more widely used. The first category might not be relevant in this study because it is interview-based and calls for direct participations of decision makers and other stakeholders. As our project is large scale with multiple-criteria, the second category would be more suitable to apply. In the second category, goal programming is one of the popular multi-criteria optimization techniques used for water resources management and planning. It provides a way of considering more than one objective function. It sets a specific numeric goal for each objective, and then seeks a solution that maximizes the weighted sum of objectives while taking a set of constraints into consideration.

The current study is an integral part of a larger project aimed to assess the feasibility of applying intra-country VWTS to alleviate water scarcity in a systematic manner. In the first step of the project, the Soil and Water Assessment Tool (SWAT) (Arnold et al., 1998) was used to quantify the water resources availability at sub-basin spatial and monthly temporal resolutions in Iran (Faramarzi et al., 2009). In the second step, we modeled the sub-basin based 
$y$, evapotranspiration (ET), and CWP in different provinces The likely effects of some policy options concerning field level management were investigated (Faramarzi et al., 2010). The results suggested that Iran is unlikely to meet its national food objectives by merely implementing measures concerning improving field level management. Biult upon the results of the previous two works, this study assesses the feasibility of applying VWTS as a policy instrument to alleviate regional water scarcity while maintaining certain level of cereal production and self-sufficiency in wheat in Iran.

Against this background, this study intends to address the following questions: (i) how to construct a systematic framework to assess the provincial ASCP and cereal production corresponding to VWTS; (ii) what are the optimum sizes of areas under cereal crops across different provinces to maximize national cereal production, while meeting a certain level of wheat self-sufficiency and water scarcity; (iii) what will be the impact of improved irrigation efficiency on wheat production, cereal production, and water scarcity alleviation; and finally, (iv) what are the implications of ASCP for intra-country virtual water trade and physical water transfers in Iran. The reason for focusing on water in this study is that water scarcity has become a major constraint in many provinces in Iran. The impact of climate change was shown to exasperate the water problems in Iran (Abbaspour et al., 2009). The rapid depletion of water resources in many provinces has posed a threat to the future food production. This means that the trend in water use in these provinces cannot be continued without facing serious ecological and economic consequences. Measures to halt the water resource over-exploitation and depletion have to be sought to prevent the situation to slide over to the point of no return. The reason for focusing on cereal crops, particularly wheat, is because of their strategic importance for food security. Other water management options also exist such as breading crops with higher yield/CWP and wastewater reuse. These should also be considered in developing a national strategy for water resources management, but their consideration is beyond the scope of the present study.

\section{Methodology and data}

\subsection{Study area}

Geographically, Iran is located between 25-40 degrees north latitude and 44-63 degrees east longitude with total area of about 1.648 million $\mathrm{km}^{2}$. Climatic conditions of Iran are mostly typical of arid and semi-arid regions. Nevertheless, the country has a wide spectrum of climatic, physiographic, edaphic, and hydrological conditions. The country-wide average precipitation is about $252 \mathrm{~mm}$ year $^{-1}$. The northern and high altitude areas in the west receive about 1600$2000 \mathrm{~mm}$ year $^{-1}$ (NCCO, 2003), while the central and eastern parts of the country receive less than $120 \mathrm{~mm}_{\text {year }}{ }^{-1}$.
Both spatial and temporal variability of water resources availability is uneven. The central, eastern and southern part of the country experience extreme weather conditions such as drought, hence, having unreliable blue water resources for development of rainfed agriculture and have a high risk of food production in the absence of irrigation. The per capita freshwater availability for the country was estimated at around $2000 \mathrm{~m}^{3}$ capita $^{-1}$ year $^{-1}$ in the year 2000 and expected to go below $1500 \mathrm{~m}^{3}$ capita $^{-1}$ year $^{-1}$ by 2030 due to population growth (Yang et al., 2003). The spatial distribution, however, shows a large variation across the country. Using the widely-used water stress indicators and taking the $1700 \mathrm{~m}^{3}$ capita $^{-1}$ year $^{-1}$ as the water scarcity threshold, our previous study (Faramarzi et al., 2009) showed that except western and some northern part, most of the country suffers from severe water scarcity. It was found that 46 million people living on about $59 \%$ of the country's area are subject to water scarcity. Winter temperatures of less than $-20^{\circ} \mathrm{C}$ in high altitude of the country and summer temperatures of more than $50{ }^{\circ} \mathrm{C}$ in some areas are recorded (NCCO, 2003).

Of the total land area of the country, $12 \%$ is under cultivation (arable land, orchards and vineyards). About 9 million hectares of this land are irrigated using traditional and modern techniques, around 6.5 million hectares are rainfed, and the rest is fallow every year. Wheat, barley, rice and maize are the country's major cereal crops. Self-sufficiency in wheat production was achieved in 2004. In 2007 Iran exported nearly 600000 tons of wheat while producing 15 million tons. However, it is reported that 8.5 million tons of wheat estimated to have been imported in 2008/09 because of the drought in 2008 (http://www.pecad. fas.usda.gov/highlights/2009/05/Iran). Iran's total rice production stands at 2.2 million tons year ${ }^{-1}$ whereas annual consumption is about three million tons (2008). Iran has long been an importer of rice and it imported about 630000 tons of rice in 2008 .

Historically, Iran was self-sufficient in terms of agricultural products until the 1960s. However, in the 1970s it turned to import food from outside of the country. In 1979 the government of Iran set the national goal for selfsufficiency in foodstuffs. Since then, commercial farming has replaced subsistence farming. High government subsidies for cereal and other staples and expansion of short-term credit and tax exemptions for farmers were provided to promote self-sufficiency. Currently, the agricultural sector accounts for almost $13 \%$ of Iran's GDP, $20 \%$ of the employed population, $23 \%$ of non-oil exports, $82 \%$ of domestically consumed foodstuffs and $90 \%$ of raw materials used in the food processing industry (Keshavarz et al., 2005; Stads et al., 2008). 


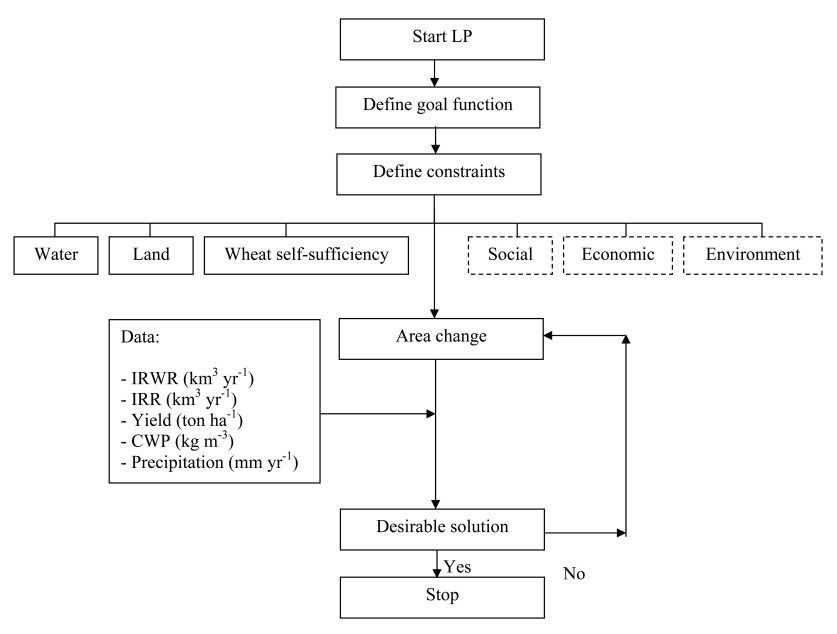

Fig. 1. Multi criteria decision analysis framework of the ASCP corresponding to the VWT strategy. IRWR: internal renewable blue water resources, IRR: irrigation water requirement, CWP: crop water productivity. Dash lines in the constraint are the factors that were not considered in this study.

\subsection{Multi-criteria analysis framework}

\section{Construction of goal function}

Use of a multi-criteria approach to ASCP facilitate accounting of the country's diverse agro-climatic, social, and economic conditions. We developed a mixed-integer, multiobjective linear optimization model and solved it by linear programming (LP). Figure 1 illustrates the framework of the ASCP developed in this study. We used the data of 19902004 in the LP procedure as the baseline to allow comparison of various scenarios. In this LP procedure, we focused on the constraints concerning water, land, and wheat self-sufficiency. The current LP procedure does not include socio-economic and environmental constraints explicitly, although some of them are partially reflected by the constraints for water, land and national food production. An explicit consideration of social, economic and environmental constraints in determining optimal ASCP will be conducted outside of the LP procedure by assessing the LP results against some of the key factors concerning social equity, economic viability and environmental sustainability (Wiek and Binder, 2005). Figure 2 summarizes construction of the LP stating the objective function as well as the constraints.

Maximizing the quantity of cereal crops at the national level is used as the main objective in the multi-criteria analysis. Hence, the objective function (Eq. 1) was formulated as the weighted sum of the average of 1990-2004 cereal production in the country, $f_{1}$, plus an adjustment factor resulting from the changes in the cropping pattern, $f_{2}$. The weights were chosen so as to equalize the effect of each component on the objective function. To maximize the objective

\begin{tabular}{|c|c|c|}
\hline Objective fn: & $\mathrm{g}=w_{1} f_{1}+w_{2} f_{2}$ & (1) \\
\hline where: & $f_{1}=\frac{1}{15} \sum_{j=1}^{28} \sum_{j=1}^{15} \sum_{k=1}^{4}\left(a_{i, j, k} \times y_{i, j, k}\right)$ & (2) \\
\hline and & $f_{2}=\sum_{i=1}^{28} \sum_{i=1}^{15} \sum_{k=1}^{4}\left(d e l t a_{i, j, k} \times a_{i, j, k}\right)$ & (3) \\
\hline where: & $\operatorname{delta}_{i, j, k}=\left(C W P_{i, j, k} \times y_{i, j, k}\right)-I_{k}$ & (4) \\
\hline & $C W P=\frac{y}{E T}$ & (5) \\
\hline & $I_{k}=\frac{1}{15} \sum_{i=1}^{28} \sum_{j=1}^{15}\left(C W P_{i, j} \times y_{i, j}\right)$ & (6) \\
\hline Constraints: & & \\
\hline Area: & $A_{i}=\frac{1}{15} \sum_{k=1}^{4} a_{i, j, k} \leq A_{t_{-} \max }$ & (7) \\
\hline where: & $p a r_{\min _{k}} \times a_{h_{-} \max _{i, k}} \times Z_{j} \leq a_{i, j, k} \leq p a r_{\max _{k}} \times a_{h_{-} \max _{i, k}}$ & (8) \\
\hline and: & $Z_{j}= \begin{cases}0 & \text { if } j \text { drought year } \\
1 & \text { if } j \text { non-drought year }\end{cases}$ & (9) \\
\hline where: & drought year if $p c p_{i, j}<\left(\frac{1}{n} \sum_{j=1}^{15} p c p_{j}\right)_{i}$ & \\
\hline Water scarcity: & $U S R_{i, j}=\frac{1}{I R W R_{i, j}}\left[\sum_{k=1}^{4} I R R_{k}+\sum_{r=1}^{16} I R R_{r}\right]_{i, j} \leq$ & (10) \\
\hline & $\operatorname{USR}_{h, i} \times Z_{j}+$ scar_tol $\times\left(1-Z_{j}\right)$ & \\
\hline where: & $I R R_{k}=10^{-8} \times a_{k} \times \frac{E T_{k}}{W E_{k}}$ & (11) \\
\hline and: & {$\left[\frac{1}{15} \sum_{j=1}^{15} U S R_{j}\right]_{i} \leq U S R_{h, i}$} & (12) \\
\hline Wheat self-sufficiency: & 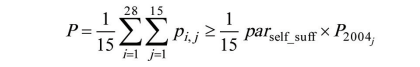 & (13) \\
\hline where: & $P_{2004_{j}}=\frac{p o p_{j}}{\text { pop }_{2004}} P_{2004}$ & (14) \\
\hline
\end{tabular}

Fig. 2. Construction of the LP model for adjustment of the structure of cropping system.

function, the areas under cultivation of cereal crops (barley, maize, rice and wheat) were varied across provinces to meet the constraints presented later in this section. As climate of Iran is quite variable across provinces, there are large differences in the performances of different crops in different parts of the country (Faramarzi et al., 2010). This performance is usually measured by the quantity of the CWP. This is defined as the amount of $y$ that can be produced by a given amount of water consumptively used in ET. Hence, the provinces with a better performance in the production of a given crop should gain more area for that crop than the provinces with poorer performance. As a large CWP could also be achieved with small $y$ and small ET, we multiplied CWP with $y$ to give more weight to regions with larger $y$. To determine the relative performance of individual provinces, we constructed the delta indicator as shown in Eq. (4). The index $I$ is the long term (1990-2004) average value of the $(\mathrm{CWP} \times y)$ at the national level. The $I$ value of barley, maize, rice and wheat were calculated to be $1.348,6.126,1.202$, and 1.551 (ton $\mathrm{kg} \mathrm{m}^{-3} \mathrm{ha}^{-1}$ ), respectively. The delta factor, therefore, is an important indicator of the marginal gain due to ASCP; for 


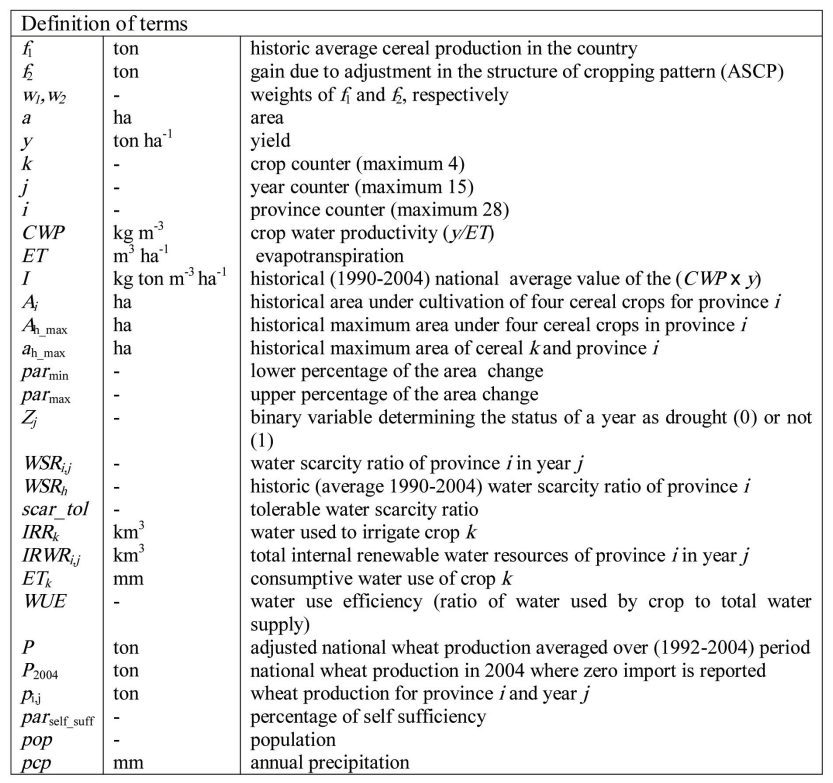

Fig. 2. Continued.

this reason it was added to the objective function to quantify the impact of the changes in cropping pattern.

\section{Setting up the constraints}

Based on historical trend in agricultural area (1990-2004) and personal interviews with agricultural experts we concluded that all agricultural areas in most of the provinces are being potentially used and can not be expanded. Even if there were potentials for expansion, these would be mostly in marginal lands located in ecologically fragile areas. The four scenarios investigated later in this paper focus on exploring the possible options to halt the blue water depletion by reducing irrigated areas in water scarce regions/provinces and expanding irrigated areas in water abundant regions/provinces. Reallocation of non-irrigated areas is not directly addressed because reducing green water use in water scarce regions generally does not help alleviate their blue water scarcity. As for the non-cropland areas, it is very difficult to predict how much and where the expansion could be possible in the future. The environmental consequences of expanding crop areas to marginal land further complicate such predictions. In this study, the scenarios are set under the assumption that crop areas will not exceed the historic maximum in each province. With this consideration, we constrained the total area under cultivation of cereal crops to not exceed historic maximums as expressed in Eq. (7).

It should be pointed out that in most parts of Iran the cereal crops are grown with a crop-fallow sequence or in rotation with chickpea or fodder legume crops (Nasiri et al., 2008; Filizadeh et al., 2007). Therefore the summer cereals (maize and rice) are generally not in rotation with winter

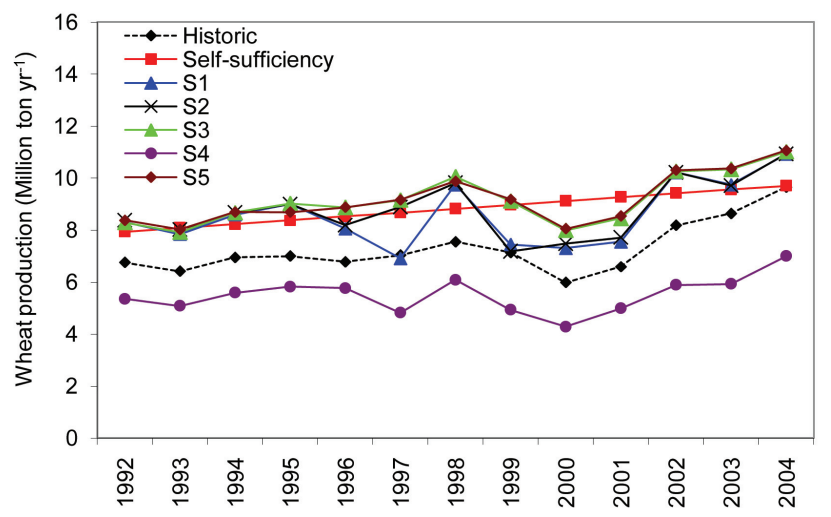

Fig. 3. National wheat production trend resulting from different water and food scenarios.

cereals (wheat and barley). The total area under cultivation was calculated as the aggregated area of the four cereal crops considered in this study $\left(A_{h-\max , i}\right.$ in Eq. 7).

In practice, it is not realistic to assume that if a province has small value of delta for a given crop, this province should give up all the production for that crop. Likewise, if a province has a high value of delta, it is not realistic to assume that all the cereal land should go for this crop. Hence, the constraint in Eq. (8) was imposed. This constraint ensures that the area change (new area assigned to a crop in a province) is smaller than the historic maximum for that province and larger than the minimum. In the drought years the minimum area is set to zero through the $Z$ binary operator in Eq. (9).

Next, we added a water scarcity constraint. Water scarcity ratio (WSR) is defined as the fraction of the total (blue) water use to the total available (blue) water resources (Alcamo et al., 2007). The constraint in Eq. (10) is set up in such a way that WSR in each province and in each year does not exceed the historical value except in drought years. In other words, there are some dry years in which WSR can equal a user-defined level of scarcity tolerance expressed as scar_tol in Eq. (10). In all, we accounted for irrigation water use of 20 crops. Our study focuses on the four cereal crops and their irrigation water uses were calculated based on the adjusted area of cultivation; hence, they are expressed separately in Eq. (10). For the other 16 crops we used total reported values for every year and province $\left(\mathrm{IRR}_{r}\right)$. In this study, we did not consider the possible adjustment of structure of these 16 crops because they are either cash crops and/or non-staple crops with less importance for food security. Lacking information on production costs and benefits as well as the complexity of the cropping systems in cash crops across regions deterred our attempt to implement ASCP for these crops in the optimization procedure. To calculate the irrigation water use of the four cereal crops $\left(\mathrm{IRR}_{k}\right.$ ), we used the consumptive irrigation water use of the crop $\left(\mathrm{ET}_{k}\right)$, or blue water consumptive use, which is the SWAT output taken from a 
Table 1. The optimized LP model parameters obtained for all scenarios.

\begin{tabular}{llllll}
\hline Parameter & $\mathrm{S} 1$ & $\mathrm{~S} 2$ & $\mathrm{~S} 3$ & $\mathrm{~S} 4$ & $\mathrm{~S} 5$ \\
\hline par $_{\text {min,barley }}$ & 0.00 & 0.00 & 0.00 & 0.00 & 0.00 \\
par $_{\text {max }, \text { barley }}$ & 0.92 & 0.92 & 0.99 & 0.93 & 1.00 \\
par $_{\text {min,maize }}$ & 0.40 & 0.04 & 0.00 & 0.00 & 0.00 \\
par $_{\text {max,maize }}$ & 0.84 & 0.95 & 1.00 & 0.92 & 1.00 \\
par $_{\text {min,rice }}$ & 0.16 & 0.00 & 0.00 & 0.00 & 0.00 \\
par $_{\text {max,rice }}$ & 0.96 & 1.00 & 1.00 & 0.99 & 1.00 \\
par $_{\text {min,wheat }}$ & 0.31 & 0.46 & 0.15 & 0.00 & 0.60 \\
par $_{\text {max,wheat }}$ & 0.98 & 0.96 & 1.00 & 1.00 & 1.00 \\
scar_tol $^{\mathrm{a}}$ & 7.70 & 7.70 & 11.90 & 1.94 & 5.60 \\
par $_{\text {self_suff }}$ & 0.89 & 0.92 & 1.00 & 0.57 & 1.00 \\
\hline
\end{tabular}

${ }^{a}$ The values are the maximum of all provinces in all years. The historical maximum value of scar_tol is 10, which was measured in Ghom and Khorasan provinces.

previous study (Faramarzi et al., 2010), and adjusted it for the water use efficiency (WUE) obtained from Dehghani et al. (1999) for each province as expressed in Eq. (11). A further water resources constraint was added Eq. (12) to ensure that in the adjusted cropping structure the long term average water scarcity of a province does not exceed its historic value. In the LP procedure, only irrigated crops and areas were considered. We did not include dryland crops because our focus was on alleviating blue water scarcity. In essence, we assumed a constant structure of dryland crops.

Finally, we added the constraint in Eq. (13) to allow wheat production to take place at different self-sufficiency levels

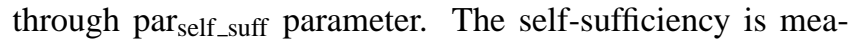
sured with respect to the per capita production level (irrigated wheat) of the year $2004\left(P_{2004}\right)$ where no import was reported. As population increases, the total cereal production required to meet the national self-sufficiency also increases, while the per capita cereal production is constant at the level of 2004.

With the above framework, the model is optimized through 10 parameters. Eight of these parameters deal with area configuration, one with water scarcity limit, and one with the degree of wheat self-sufficiency (Table 1).

\subsection{Data compilation and scenario development}

Table 2 gives detail information on the data type, source of data, spatial and temporal resolution of the available data, and the time period used in the study. The IRWR is defined as the sum of stream flow and deep aquifer recharge. The IRWR data was modeled at the sub-basin spatial and monthly temporal resolution in our previous study, where the soil wa- ter balance equation was the basis of hydrological modeling. The simulated processes include surface runoff, infiltration, evaporation, plant water uptake, lateral flow and percolation to shallow and deep aquifers. The crop yield was modeled while taking the effect of all management stress factors (water, fertilizer, and temperature) and the crop water productivity was estimated by dividing the modeled yield by actual ET. An extensive calibration validation and uncertainty analyses of the SWAT model of Iran were also conducted (Faramarzi et al., 2009, 2010).

The previously developed hydrological model of Iran was re-calibrated and validated for irrigated rice, barley, and maize $y$ for the period of 1990 to 2004 with a similar procedure as described in Faramarzi et al. (2010) for wheat. The outputs of the sub-basin-based model were aggregated to provincial level and were used as an input to the multicriteria analysis model developed in this study for investigating potential crop pattern change in Iran.

Five scenarios were examined using the data of 1990-2004 as a base to assess water and food situation in Iran. These scenarios are described in Table 3 and further discussed in the next section.

\section{Results and discussion}

\subsection{ASCP under different scenarios and its national impact}

The optimum parameter values for each scenario are given in Table 1. Water scarcity parameter imposes a limit on water use in a province. The historic maximum value of water scarcity ratio is calculated to be around 10 for two waterscarce provinces of Ghom and Khorasan. In all scenarios, except S3, the value of WSR improved to less than the historic value.

In S1, we initially set the wheat production to the selfsufficiency level but then relaxed this constraint as there were no solutions. This indicates that under the current management situation, it is not possible to reach wheat selfsufficiency. Annual trend of wheat production for all scenarios are illustrated in Fig. 3. The quantities of cereal production obtained by solving the ASCP optimization problem are 13.3 and 14.2 million tons year $^{-1}$ in scenarios S1 and S2, respectively, as compared to the historic average amount of 12.5 million tons year ${ }^{-1}$ on the irrigated land (Table 4). The self-sufficiency level based on the per capita production of 2004 was calculated to be $142 \mathrm{~kg} \mathrm{capita}^{-1}$ year $^{-1}$ for irrigated wheat. The average wheat production in the country during 1990-2004 was 24\% lesser than the self-sufficiency level. This was improved to $10 \%$ and $8 \%$ in the S1 and S2, respectively. At the same time, the national WSR decreased from 0.73 (historic value) to 0.72 in $\mathrm{S} 1$ and increased to 0.75 in S2. The increase of WSR in S2 was due to the increased water use in water-abundant provinces. 
Table 2. List of the data used in this study. Data were available for the period of 1990-2004 except ET and historical water use efficiency which are long-term average (1990-2004) values.

\begin{tabular}{|c|c|c|c|}
\hline Data group & $\begin{array}{l}\text { Data availability } \\
\text { (criteria) }\end{array}$ & Data source & $\begin{array}{l}\text { Spatial/temporal } \\
\text { resolution }\end{array}$ \\
\hline Hydrology & $\begin{array}{l}\text { Volume of blue water resources } \\
\text { availability, IRWR }\left(\mathrm{km}^{3} \text { year }\right.\end{array}$ & $\begin{array}{l}\text { SWAT prediction } \\
\text { (Faramarzi et al., 2009) }\end{array}$ & Sub-basin, monthly \\
\hline \multirow[t]{2}{*}{ Climate } & Precipitation (mm) & (Faramarzi et al., 2009) & Sub-basin, daily \\
\hline & Crop yield (ton ha ${ }^{-1}$ ) & $\begin{array}{l}\text { MOJA and SWAT prediction } \\
\text { (Faramarzi et al., 2010) }\end{array}$ & $\begin{array}{l}\text { Crop specific, } \\
\text { provincial, annual }\end{array}$ \\
\hline \multirow[t]{4}{*}{ Agriculture } & $\begin{array}{l}\text { Cereal crop water productivity } \\
(\mathrm{CWP})\left(\mathrm{kg} \mathrm{m}^{-3}\right)\end{array}$ & $\begin{array}{l}\text { SWAT prediction } \\
\text { (Faramarzi et al., 2010) }\end{array}$ & $\begin{array}{l}\text { Crop specific, } \\
\text { provincial, annual }\end{array}$ \\
\hline & $\begin{array}{l}\text { Crop water consumption, ET } \\
\left(\mathrm{mm} \mathrm{year}^{-1}\right)\end{array}$ & $\begin{array}{l}\text { (Farshi et al., 1997) and SWAT prediction } \\
\text { (Faramarzi et al., 2010) }\end{array}$ & $\begin{array}{l}\text { Crop specific, } \\
\text { provincial }\end{array}$ \\
\hline & Historical water use efficiency & (Dehghani et al., 1999) & Provincial specific \\
\hline & Area under cultivation of crop (ha) & MOJA $^{\mathrm{a}}$ & Provincial, annual \\
\hline \multirow{2}{*}{ Population } & - & $\mathrm{SCI}^{\mathrm{b}}$ & Provincial \\
\hline & - & SCI & National \\
\hline
\end{tabular}

a MOJA: Ministry of Jahad-e-Agriculture. ${ }^{\text {b }}$ SCI: Statistic Center of Iran.

Table 3. Description of the five scenarios modelled in this study.

\begin{tabular}{|c|c|c|}
\hline Scenarios & Conditions & Description \\
\hline S1 & $\begin{array}{l}\text { Constraints as described in the LP of } \\
\text { Fig. } 1\end{array}$ & $\begin{array}{l}\text { Continuing the historic trend } \\
\text { with constraints limited by } \\
\text { historical values }\end{array}$ \\
\hline S2 & $\begin{array}{l}\text { WSR in } 10 \text { water abundant provinces } \\
\text { allowed to be higher than historic values, } \\
\text { up to a maximum of } 0.7 \text { (leaving } 30 \% \text { for } \\
\text { environmental flow Yuan et al., 2006) }\end{array}$ & $\begin{array}{l}\text { Continuing the historic trend } \\
\text { while giving flexibility to water } \\
\text { use in water abundant provinces } \\
\text { for food production }\end{array}$ \\
\hline S3 & $\begin{array}{l}\text { Restrictions on WSR were relaxed in all } \\
\text { privinces to produce maximum cereal and } \\
\text { and wheat at self sufficiency level }\end{array}$ & $\begin{array}{l}\text { This scenario is in favour of } \\
\text { of food security. The practice will } \\
\text { of course not be sustainable }\end{array}$ \\
\hline S4 & $\begin{array}{l}\text { Cereal crops were not grown in seven } \\
\text { water-scarce provinces where WSR }>1 \text {, } \\
\text { and maximized in others, while limiting } \\
\text { WSR to } 1\end{array}$ & $\begin{array}{l}\text { This scenario is in favour of } \\
\text { water security. }\end{array}$ \\
\hline S5 & $\begin{array}{l}\text { WUE in (Eq. 11) was raised to } 70 \% \text { in all } \\
\text { provinces instead of its historic value of } \\
(15 \%-36 \%)\end{array}$ & $\begin{array}{l}\text { Improved irrigation networks } \\
\text { and water conveyance systems } \\
\text { is one of the proposed } \\
\text { approaches to improve water } \\
\text { use efficiency in Iran (NRC, } \\
2005 \text { ) }\end{array}$ \\
\hline
\end{tabular}

In S3, production of all four crops increased in most provinces except barley and maize that partially decreased in some northern and southern areas. Without water con- straint, on the average, wheat could have been produced at the self-sufficiency level during 1990-2004. In wet years it was slightly above the self-sufficiency level whereas in 
Table 4. Irrigated cereal production and water scarcity ratio at national level averaged over 1990-2004 for historic and scenario results.

\begin{tabular}{lllllll}
\hline Scenarios & \multicolumn{5}{c}{ Production (million t year $\left.{ }^{-1}\right)$} & $\begin{array}{l}\mathrm{WSR}^{\mathrm{a}} \\
\left(\mathrm{km}^{3} \mathrm{~km}^{-3}\right)\end{array}$ \\
& Barley & Maize & Rice & Wheat & Cereal & \\
\hline Historic & 1.8 & 1.0 & 2.4 & 7.3 & 12.5 & 0.73 \\
S1 & 1.4 & 0.9 & 2.4 & 8.6 & 13.3 & 0.72 \\
S2 & 1.6 & 1.3 & 2.5 & 8.9 & 14.2 & 0.75 \\
S3 & 2.0 & 1.3 & 2.8 & 9.6 & 15.7 & 0.85 \\
S4 & 0.7 & 1.1 & 2.5 & 5.5 & 9.8 & 0.58 \\
S5 & 1.9 & 1.3 & 2.7 & 9.6 & 15.6 & 0.53 \\
\hline
\end{tabular}

${ }^{a}$ WSR: water scarcity ratio which is water use divided by renewable water availability.

dry years it was below (Fig. 3). However, the high level of cereal production in this scenario could not be sustainable in the long term because the national WSR increased from 0.73 to 0.85 . Relaxing the restriction on water use will lead to groundwater over extraction and exhaustion in many provinces in arid and semi-arid regions. This scenario will be exasperated by the impact of climate change as it was shown previously (Abbaspour et al., 2009) that in dry regions groundwater recharge will substantially decrease due to a decrease in higher intensity rainfall events.

In S4, the optimal ASCP strongly depended on the WSR. In this scenario, cereal crops were either eliminated or significantly decreased in most parts of the country. Wheat production could only meet $60 \%$ of the self-sufficiency level. The national average WSR decreased from 0.73 to 0.58 , indicating a significant reduction in the pressure on the country's water resources.

In S5, where all provinces were assumed to increase their irrigation water use efficiency to $70 \%$, wheat and other cereal production were larger than historic levels. Self-sufficiency was also achieved for wheat while WSR decreased from 0.73 to 0.53 . These results suggest that improving water use efficiency in irrigation along with restructuring cropping pattern can substantially alleviate the water scarcity situation, while supplying more food at the same time.

\subsection{ASCP under different scenarios and its provincial impact}

Figure 4 shows the structure of cropping pattern in the period of 1990-2004 across the country (the historic pattern). Figures 5 (S1-S5) show the respective changes under the five scenarios. The coloured circles show the percent deviation in cropping areas for various scenarios from the historic average levels. The background colours show the delta index, with positive values (blue colour) indicating better performance $(\mathrm{CWP} \times y)$ than the national average and negative values (red colour) indicating worse performance. Ideally, VWTS dic- tates that provinces with better performance for a given crop should in general gain more area for that crop than provinces with poorer performance. Figure 5 (S1 and S2) show this trend for all cereals except wheat. In general, barley, rice, and maize show a decrease in provinces with negative delta and increase in provinces with positive delta. As wheat selfsufficiency is an additional driving force in the LP model, its area was increased in all provinces. In S1, rice is removed or largely decreased in most of the provinces where CWP is small except some northern provinces where CWP of rice is large. For example, we may compare the arid central province of Esfahan with the water abundant northern province of Gilan. Gilan has the long-term average annual $y$ equal to $6.1 \mathrm{ton} \mathrm{ha}^{-1}$ and CWP of $0.31 \mathrm{~kg} \mathrm{~m}^{-3}$ resulting in a performance value of 1.891. Esfahan has the average $y$ equal to 3.9 ton $\mathrm{ha}^{-1}$ and CWP of $0.57 \mathrm{~kg} \mathrm{~m}^{-3}$ resulting in a performance value of 2.222. Considering the national performance value for rice $\left(1.202 \mathrm{ton}_{\mathrm{kg} \mathrm{m}}^{-3} \mathrm{ha}^{-1}\right.$ ), both provinces have high performances with a positive delta value. As water scarcity (represented by WSR) is a limiting factor in Esfahan province, the LP model sought to reduce the rice production area in Esfahan despite its high performance. A reduction in rice cultivation area in the central and southern provinces will alleviate water scarcity, since the evaporative demand in these areas is extremely high and large amounts of water are required for paddy cultivation.

Relaxing WSR in some water abundant provinces (as defined in S2), led to slightly different adjustment in the structure of cropping pattern (Fig. 5). Rice cultivation was increased in water-abundant provinces. Maize was expanded in most parts of the country with high maize production performance. The area of barley cultivation was slightly increased in some provinces.

Results of S3 show that wheat areas increase in all provinces, resulting from the removal of restrictions on WSR to allow maximum wheat production (Fig. 5). The area changes of the other cereals are again mostly consistent with VWTS.

In $\mathrm{S} 4$, where water sustainability is given a higher priority, the cereal crop areas are decreased in the eastern part of the country, where water scarcity is severe, while wheat production is increased in the western part of the country where water scarcity is not critical (Fig. 5 S4). Rice and maize production are highly consistent with VWTS, and barley is decreased in most of the provinces.

In S5, water scarcity was found to be less of a limiting factor than in S1 and S2 due to the assumed improvement in the irrigation efficiency. Therefore, the LP model sought to maximize cereal production and to meet wheat at the selfsufficiency level while using less water than S1 and S2. We found a rather similar cropping pattern as S3 in this scenario but with less WSR in individual provinces as well as at the national level (Fig. 5 S5). 

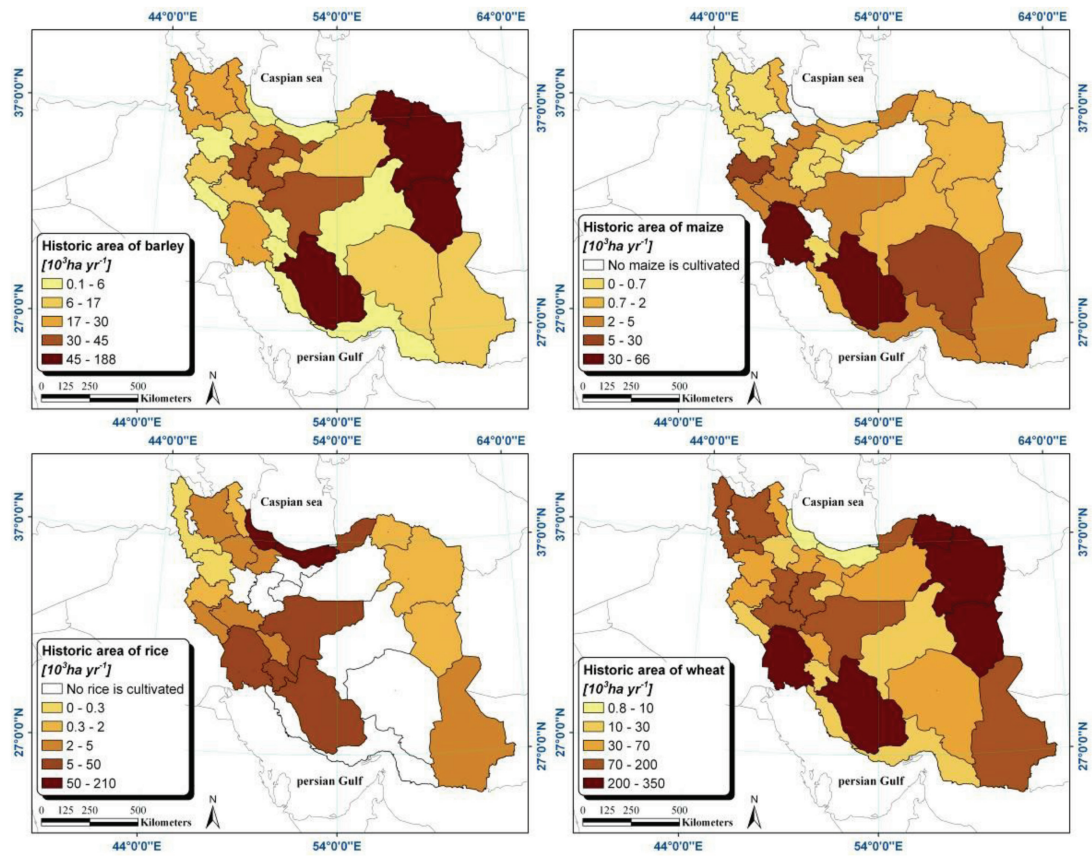

Fig. 4. Long-term (1990-2004) average area under cultivation of cereal crops which is historically practiced at different provinces.
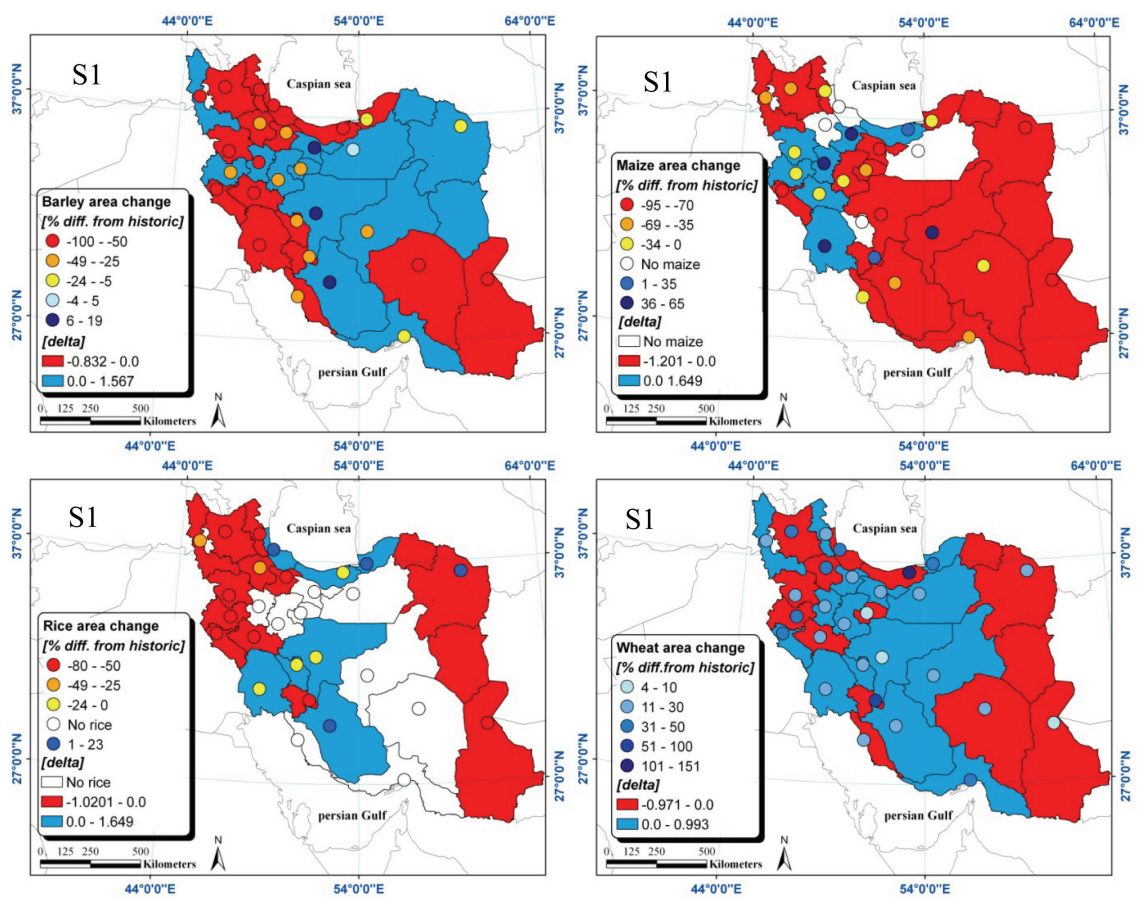

Fig. 5. Adjusted structure of cropping pattern in S1 to S5. Circles show \% differences from the long-term (1990-2004) average area in Fig. 4. The background colors show the provinces delta index where blue indicates positive performance and red indicates negative performance with respect to national average. 

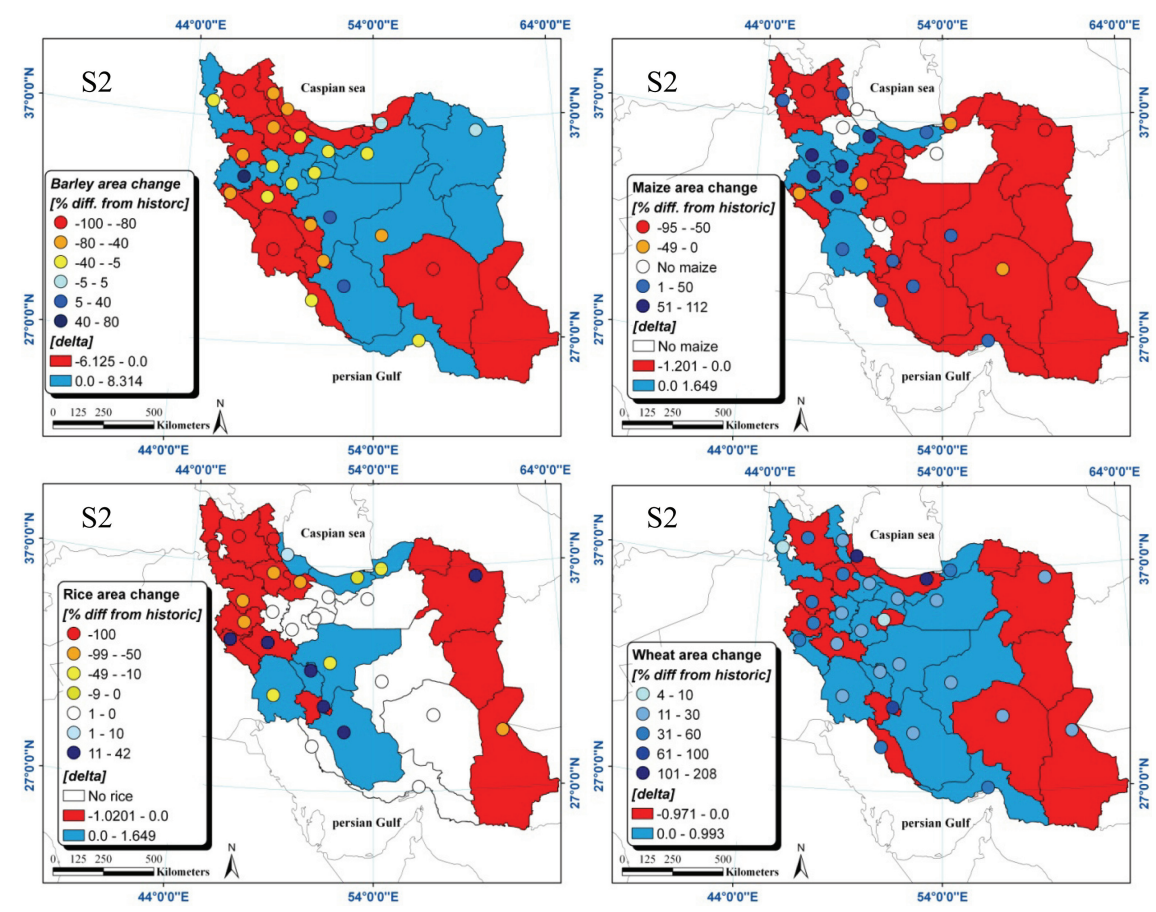

Fig. 5. Continued.
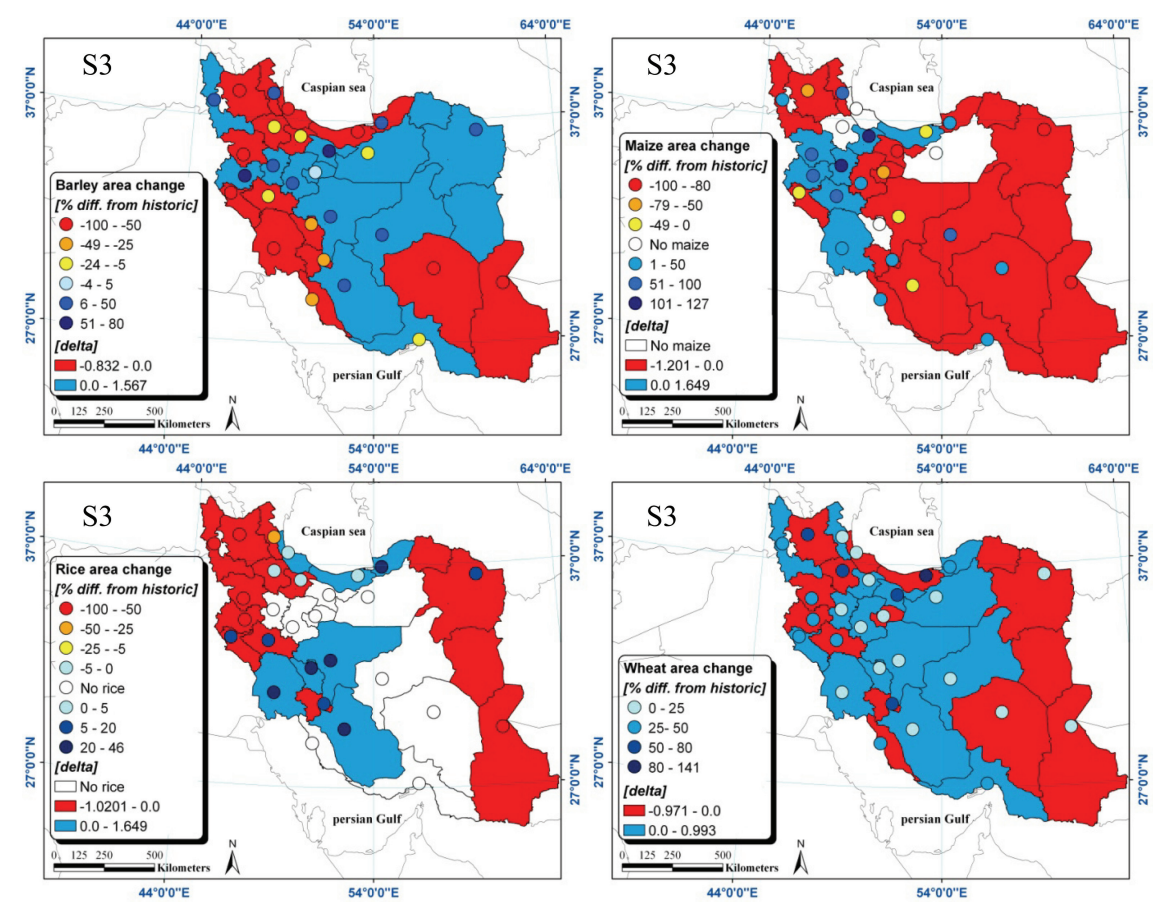

Fig. 5. Continued. 

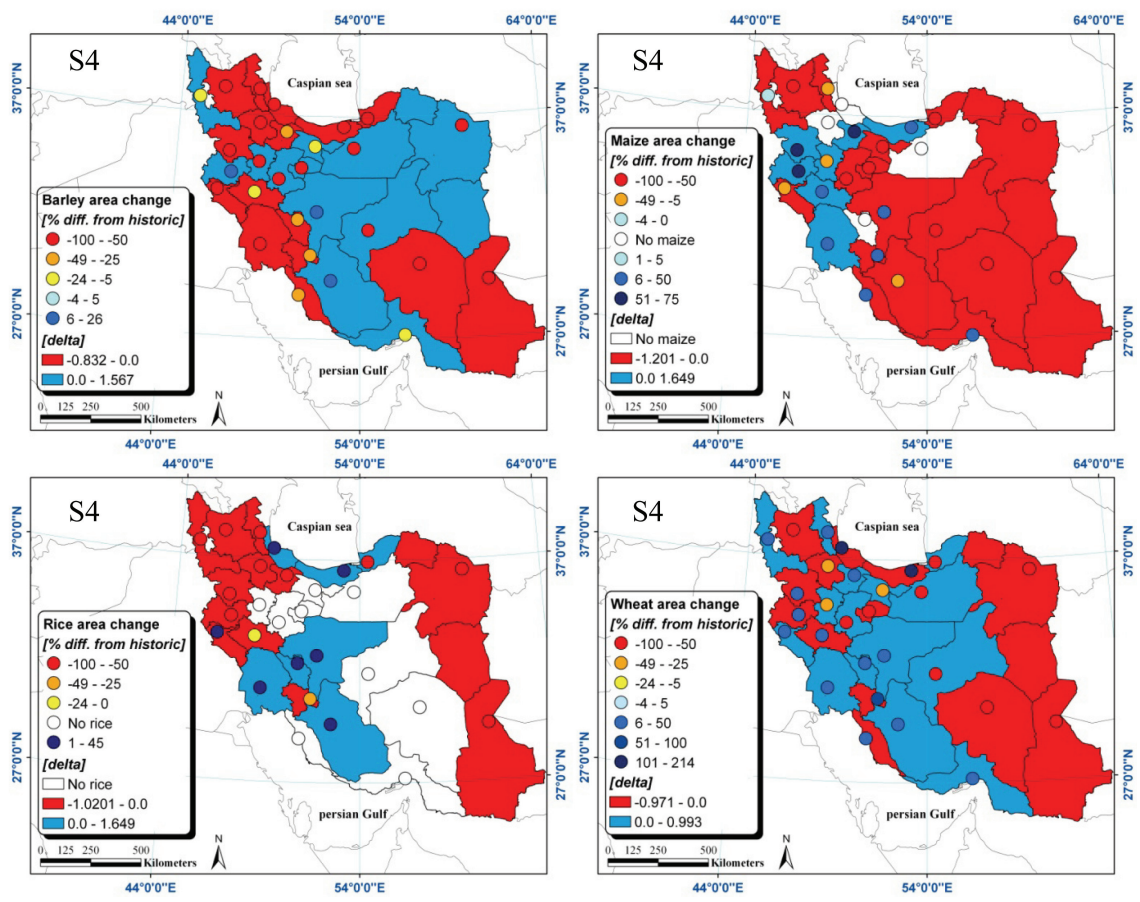

Fig. 5. Continued.
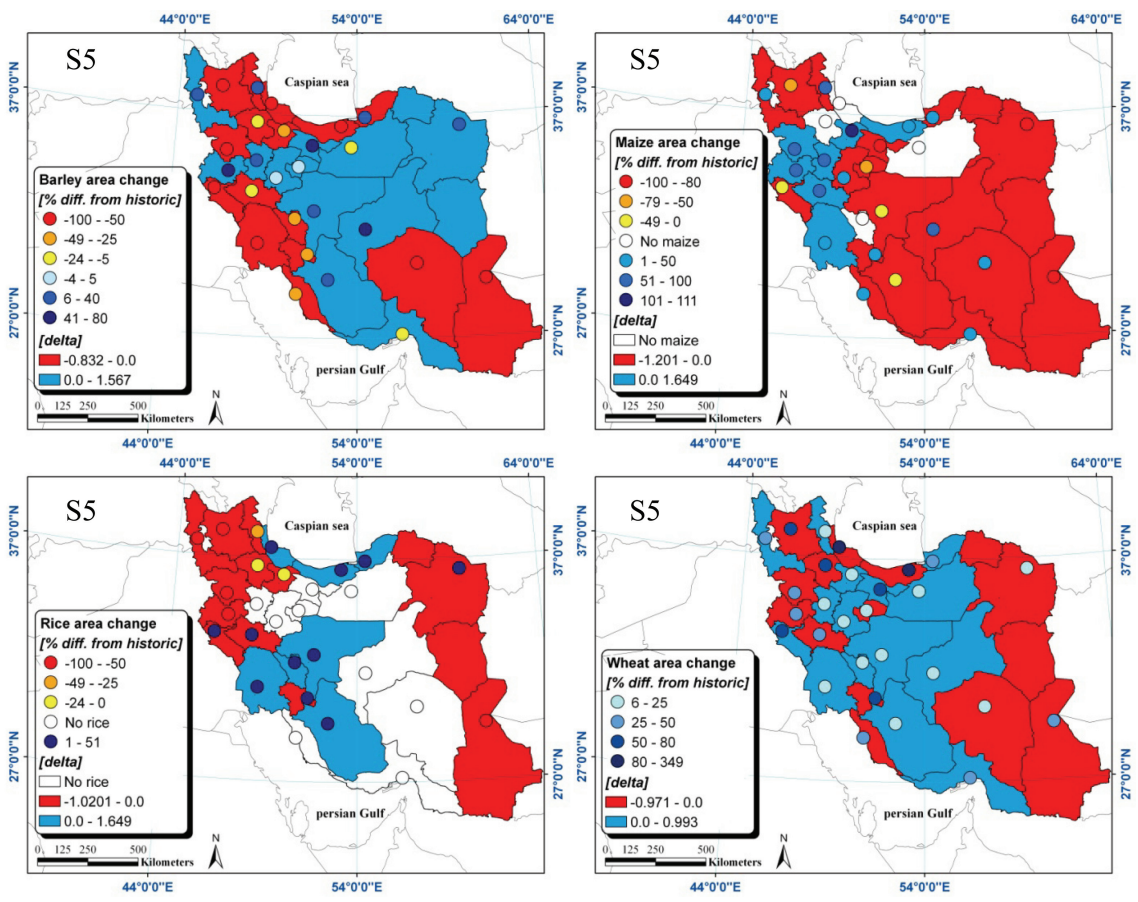

Fig. 5. Continued. 

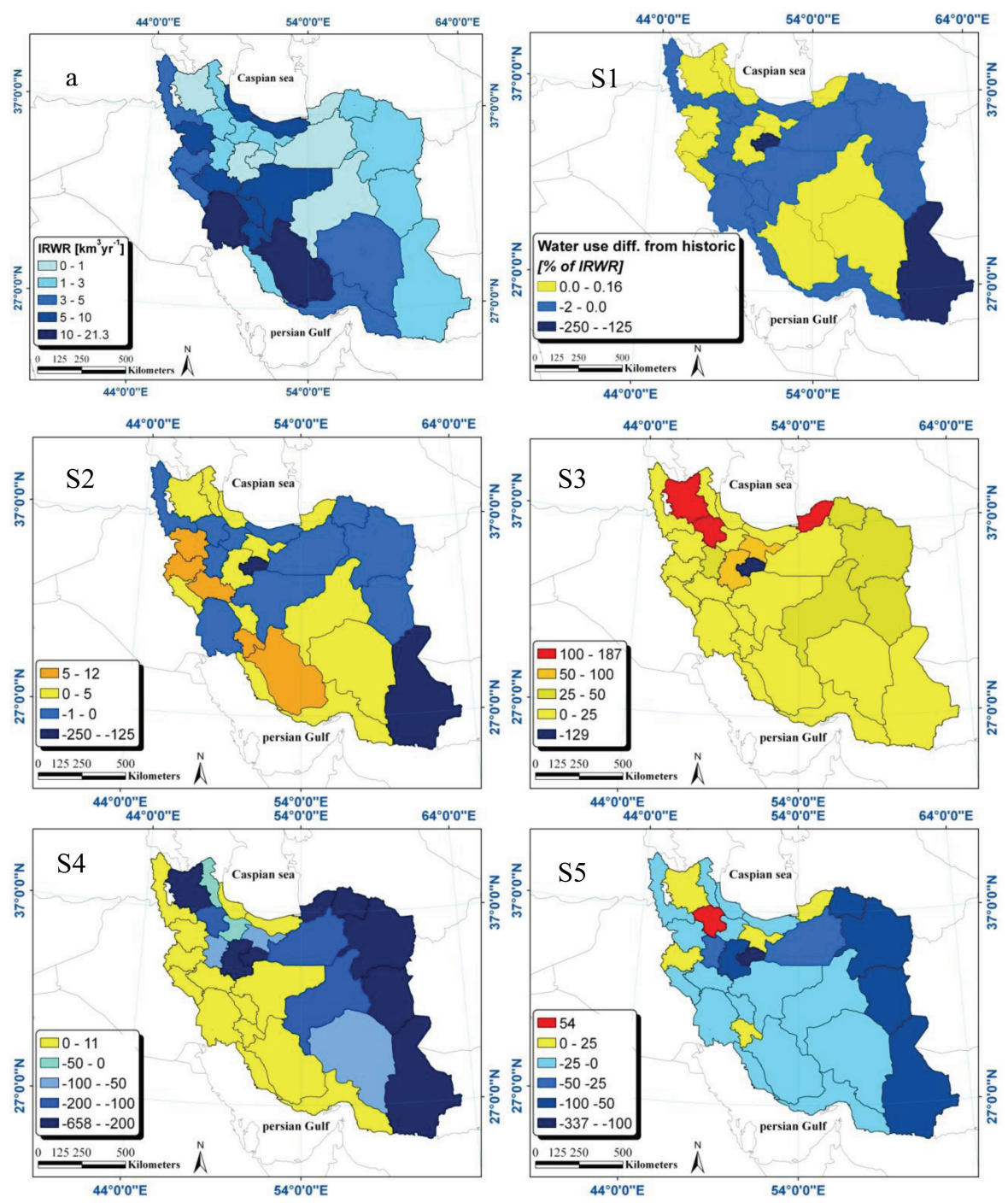

Fig. 6. Map of the differences in water use as percentage of internal renewable water resources resulting from adjustment in the structure of cropping pattern. Figure 6 a shows the historic distribution of the internal renewable blue water resources (IRWR). The blue areas show a decrease in water use.

\subsection{Impact of ASCP on WSR in different provinces}

Figure 6 shows how the optimized ASCP scenarios would change blue water use relative to the current IRWR. In S1 and S2, most of the wet regions in the west and north of the country and some provinces in the south would use up to $12 \%$ more of their blue water resources, while water use in the eastern and central dry provinces would slightly decrease with respect to their IRWR. A reduction in water use by more than $100 \%$ implies lesser use of deep fossil groundwater and/or other external sources.

S3 would lead to increase in water use by up to $200 \%$ of renewable blue water resources in some northern provinces and $0-50 \%$ in the dry central and eastern regions. Increasing the water use in regions where water scarcity is already se- vere will not be sustainable and agricultural production will eventually decrease due to the lack of water and soil erosion such as salinity. Ghom is the only province for which a decrease of water use is predicted in this scenario. As the IRWR of Ghom province is meager, a decrease of $128 \%$ in water use will not drastically improve the situation. This scenario shows that under the current practice, achieving long term wheat self-sufficiency is impossible.

In S4, the eastern half of the country and most of the northwestern provinces will decrease water use by up to $600 \%$ of their respective IRWR. In many parts of Iran, water supply solely depends on groundwater. During the past two decades, overexploitation of groundwater has caused a water table drawdown in most of the 600 aquifers in Iran (Motagh 

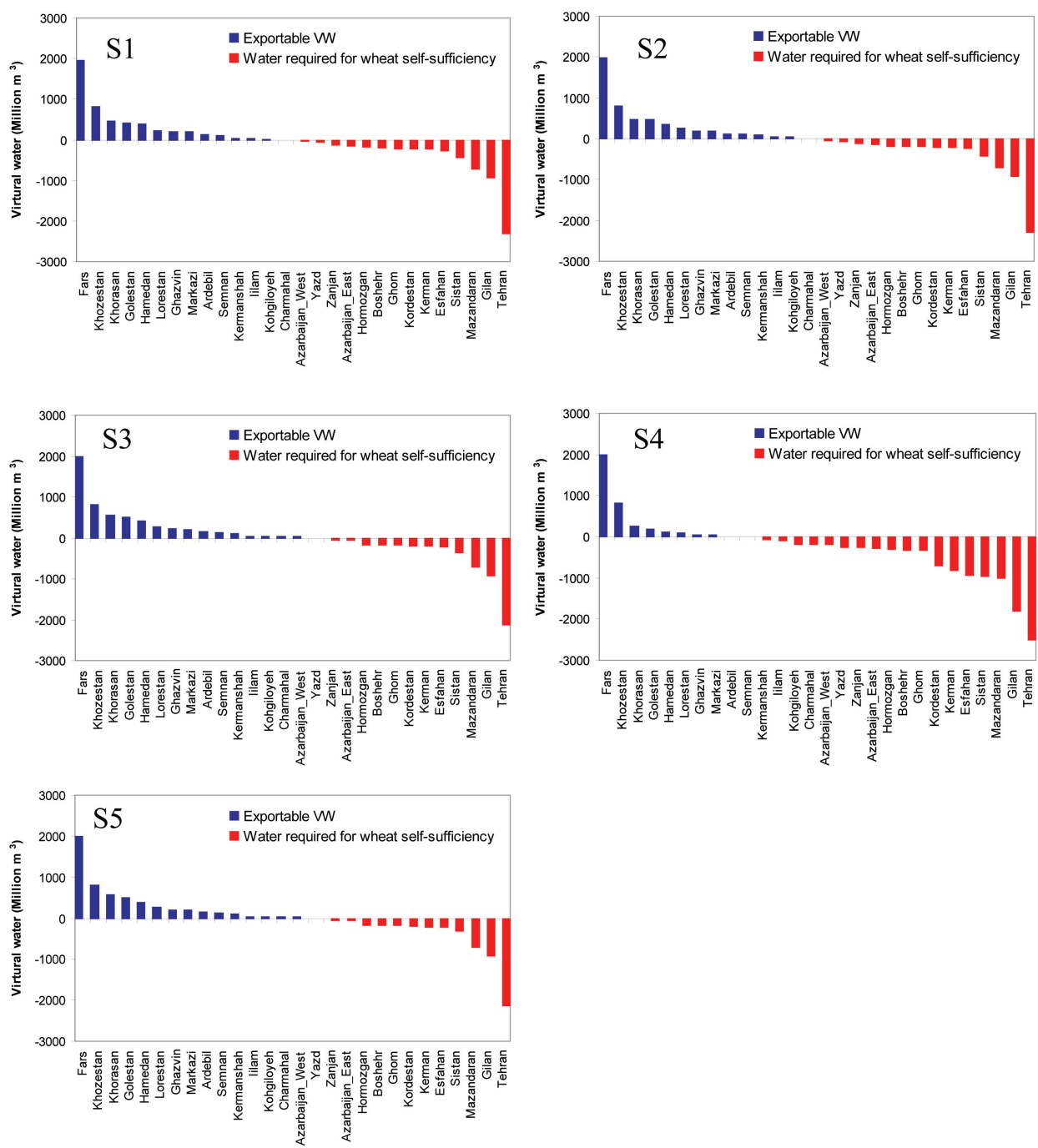

Fig. 7. Long-term (1990-2004) average virtual water exported through wheat trade in provinces where excess wheat is produced (blue) and the amount of water required to produce wheat in the importing provinces (red).

et al., 2008). Akhavan et al. (2010) reported a 50-m drawdown in the province of Hamedan in western Iran in the past 30 years. Reducing water use is absolutely necessary to halt the groundwater drawdown.

In S5, water use is decreased by $25 \%$ of IRWR in the central part of the country and up to $100 \%$ in the eastern region. Khorasan province located in the north east of Iran is one of the major wheat producers in the country and has a large area under wheat cultivation. Reduction in the water use by up to $100 \%$ of the IRWR in this province would have a significant impact on the conservation of water resources in the region and consequently on the availability of water for wheat production in the long run.

\section{Implications of ASCP}

\subsection{Implications of ASCP scenario results for interre- gional VWTS}

We used the provincial data to study the possible interprovincial trade under different ASCP scenarios. Using the provincial population data of 1990-2004 and the wheat selfsufficiency benchmark of $142 \mathrm{~kg}_{\text {capita }}{ }^{-1}$ year $^{-1}$, we calculated the annual provincial wheat requirement to meet the self-sufficiency level. Furthermore, we calculated deviation of the scenario results from the self-sufficiency level to estimate wheat surplus or deficit in individual provinces. Moreover, we divided the resulted wheat surplus/deficit values by the CWP $\left(\mathrm{kg} \mathrm{m}^{-3}\right)$ of wheat in different provinces to obtain virtual water content. In doing so, we calculated the amount 
Table 5. Major inter-basin water transfer projects in Iran.

\begin{tabular}{llll}
\hline Pource & Recipient & Purpose & $\begin{array}{l}\text { Volume of water } \\
\text { transfer (MCM) }\end{array}$ \\
\hline Chaharmahal Bakhtiary & Esfahan & A, M, I & 1100 \\
Mazandaran & Golestan & A, M, I & 890 \\
Kordestan & Kermanshah & A & 700 \\
Khozestan & Iilam & A & 500 \\
Fars & Bushehr & A & 500 \\
Tehran & Tehran & A, M & 420 \\
Esfahan & Fars & A, M, I & 320 \\
Chaharmahal Bakhtiary & Esfahan & A, M, I & 297 \\
Gilan & Mazandaran & A & 280 \\
Chaharmahal Bakhtiary & Esfahan & A, M, I & 268 \\
Kordestan & Kordestan & A, M, I & 250 \\
Chaharmahal Bakhtiary & Esfahan & A, M, I & 246 \\
Esfahan & Esfahan & A, M, I & 220 \\
Chaharmahal Bakhtiary & Kerman & A & 200 \\
Esfahan & Esfahan & A, M, I & 120 \\
Esfahan & Esfahan & A, M, I & 100 \\
Kermanshah & Kermanshah & A, M & 40 \\
\hline
\end{tabular}

a A: agriculture, M: municipal, I: industry. ${ }^{\mathrm{b}} \mathrm{MCM}$ : million cubic meter per year.

of virtual water in the form of wheat trade between surplus and deficit provinces. Figure 7 illustrates the average of these values over 1990-2004 period in different provinces. In all scenarios, we found a large amount of tradable virtual water due to wheat surplus in the provinces of Fars, Khozestan, Khorasan, Golestan, Hamedan, Lorestan, Ghazvin, and Markazi. This virtual water can be exported to provinces with wheat deficit, where large amounts of water would otherwise be needed to produce the same quantity of wheat (shown as red bands). Aggregating these values on the national scale, we found that wheat export from wheat surplus provinces would compensate $89 \%$ of wheat deficit in the S1 scenario, $92 \%$ in S2, 100\% in S3, 31\% in S4 and $100 \%$ in S5. In total, wheat-deficit provinces would receive 5.5 billion $\mathrm{m}^{3}$ of virtual water by importing wheat in the S1 scenario, 5.1 billion $\mathrm{m}^{3}$ in $\mathrm{S} 2,5.4$ billion $\mathrm{m}^{3}$ in $\mathrm{S} 3,3.5$ billion $\mathrm{m}^{3}$ in $\mathrm{S} 4$ and 5.4 billion $\mathrm{m}^{3}$ in $\mathrm{S} 5$. A similar analysis of the VWT potentials for other cereal crops shows that the intra-country VWT is a valid option to balance water resources between water-abundant and water-scarce provinces. This would be a promising strategy for the country from the point of view of sustainable use of water resources. The reduction of cereal production in importing provinces, however, is also likely to result in lesser income in these provinces. But the water saved due to a larger efficiency in production could be used in higher valued production such as greenhouses and hydroponics, or in more profitable industries. Yet, the VWT strategy has not been implemented in the country. This is mainly because of the former, i.e., real water costs are not reflected in the production prices. In most of the cases, water is still provided free of charge.

\subsection{Implications of ASCP scenarios for water transfer projects in Iran}

ASCP and intra-country VWT could be an alternative for water transfer projects, which are usually costly and environmentally unfriendly and destructive. Table 5 shows the volume of water which is transferred from source to recipient basins through 17 major water transfer projects for agricultural purposes in Iran. As the irrigated agriculture is the largest water user (more than 90\%) and wheat is the 
dominant crop in terms of sown area and water requirement, we assumed that $90 \%$ of the water transfer in the multipurpose projects (A, M, I and A, M in Table 5) and 100\% of the water in A-purpose projects are diverted to irrigate wheat. Ignoring the possible water loss due to transfer from source to recipient basin, we used the volume of water transferred to calculate the amount of wheat which could be produced in the recipient basin. We then calculated the volume of water use if that much wheat would be produced in the source basin. Figure 8 compares the volumes of water use in the recipient basin and in the source basin for the given amount of wheat produced in the two basins. It is seen that out of 17 water transfer projects only six show a higher water use in the source basin to produce a given amount of wheat than the recipient basin. In the rest of the projects the volume of water required in recipient basin is larger than the source basin. This implies that the water is transferred from the areas with higher CWP to the areas with lower CWP. The results here suggest that most of the water transfer projects in Iran may not be efficient from water resources utilization point of view for wheat production.

\section{Limitations of the study and further research}

It is important to note that the approaches used in this study do not account for some important factors influencing food trade and decision making of governments and farmers. For instance water quality is an important issue that should be carefully assessed in the analysis of VWTS (Dabrowski at al., 2009). It has been shown that (Afkhami et al., 2007) water withdrawal and its allocation to agriculture is one of the direct factors adversely affecting water quality of the KarounDez river systems in Iran. Therefore, the environmental impact of agricultural activities in exporting provinces needs more precise assessment in the intra-country VWTS. Other factors such as socio-economy (e.g. social adaptive capacity, unemployment, immigration, social equity, farm income, etc.) and national security considerations (Qadir et al., 2003; Chapagain et al., 2006) are also essential in VWTS studies. In our multi-criteria model, we took water in the centre of ASCP and VWTS analyses and ignored the other factors mostly due to lack of data. But as we build a database, these factors will be addressed in future studies.

Another limitation in this study is the uncertainty analysis that we did not address due to a deterministic nature of the optimization procedure used in this work. Accounting for input data uncertainty would be relevant for providing results with more confidence.

Finally, we assessed in this study the intra-country VWTS potentials to improve water and food security using water resources, agricultural, population, and climate data from 1990 to 2004. The impacts of global climate change on water resources availability (Abbaspour et al., 2009) and on irrigated and rainfed cereal crop yields should also be

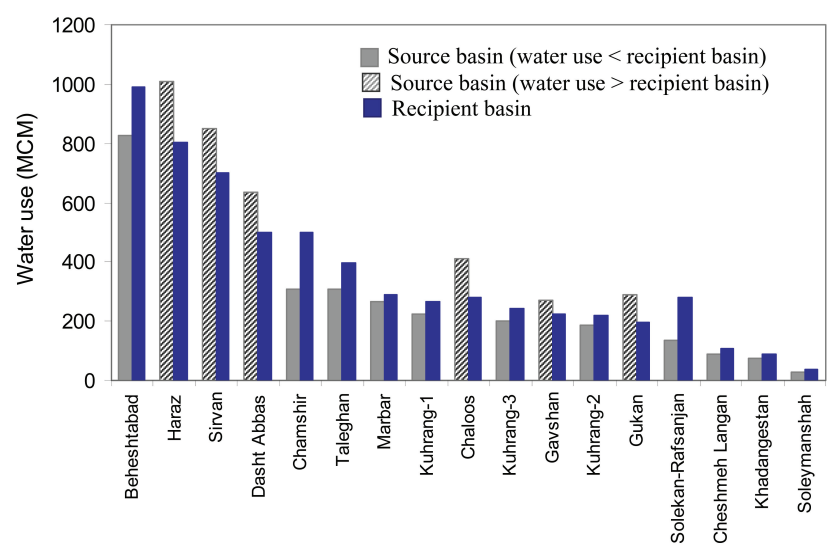

Fig. 8. Comparison of the volumes of water use in the recipient basin and in the source basin for a given amount of wheat produced in the two basins. The water use in recipient basin is real water transfer and in the source basin is virtual water that could be transferred via wheat export to the recipient basins of major water transfer projects in Iran.

addressed while assessing the feasibility of intra-country VWTS in any country. Furthermore, the current work does not address all aspects of developing a national strategy for water resources management, as we do not consider other water management options such as breading crops with higher yield/CWP and wastewater reuse. We have however, in the present work, laid out a basic framework for a more complete analysis.

Edited by: J. Liu

\section{References}

Abbaspour, K. C., Faramarzi, M., Ghasemi, S. S., and Yang, H.: Assessing the impact of climate change on water resources in Iran, Water Resour. Res., 45, W10434, doi:10.1029/2008WR007615, 2009.

Afkhami, M., Shariat, M., Zaafarzadeh, N., Ghadiri, H., and Nabizadeh, R.: Reginal water quality management for the Karun-Dez river basin, Iran, Water Environ. J., 21, 192-199, doi:10.1111/j.1747-6593.2007.00070, 2007.

Agha, S. R.: Use of goal programming and integer programming for water quality management - A case study of Gaza Strip, Eur. J. Oper. Res., 174, 1991-1998, doi:10.1016/j.ejor.2005.06.007, 2006.

Alcamo, J., Flörke, M., and Märker, M.: Future long-term changes in global water resources driven by socio-economic and climatic changes, Hydrolog. Sci. J., 52(2), 247-275, doi:10.1623/hysj.52.2.247, 2007.

Allan, J. A.: "Virtual Water": A Long Term Solution for Water Short Middle Eastern Economies?', Occasional Paper, SOAS Water Issues Group, King's College, UK, 1997.

Al-Zahrani, M. A. and Ahmad, A. M.: Stochastic goal programming model for optimal blending desalinated water 
with groundwater, Water Resour. Manag., 18, 339-352, doi:10.1023/B:WARM.0000048487.05662.88, 2004.

Akhavan, S., Mousavi, S. F., Abedi-Koupai, J., and Abbaspour, K. C.: Conditioning DRASTIC model to simulate nitrate pollution, Case study: Hamadan-Bahar Plain, Environ. Geol., in review, 2010.

Ardakanian, R.: Overview of water management in Iran, in Water Conservation, Reuse, and Recycling: Proceeding of an IranianAmerican workshop, The National Academies Press, Washington, DC, 18-33, 2005.

Chapagain, A. K., Hoekstra, A. Y., and Savenije, H. H. G.: Water saving through international trade of agricultural products, Hydrol. Earth Syst. Sci., 10, 455-468, doi:10.5194/hess-10-4552006, 2006.

Dabrowski, J. M., Murray, K., Ashton, P. J., and Leaner, J. J.: Agricultural impacts on water quality and implications for virtual water trading decisions, Ecol. Econ., 68, 1074-1082, doi:10.1016/j.ecolecon.2008.07.016, 2009.

Dehghani, S. H., Alizadeh, A., and Keshavarz, A.: Implementation of Water Use Pattern in Terms of Volumetric Supply of Water to Farmers, Iranian Agricultural Research Institute (IAERI) Press, Tehran, Iran , 1999 (in Persian).

Faramarzi, M., Abbaspour, K. C., Schulin, R., and Yang, H.: Modelling blue and green water resources availability in Iran, Hydrol. Process., 23(3), 486-501, doi:10.1002/hyp.7160, 2009.

Faramarzi, M., Yang, H., Schulin, R., and Abbaspour, K. C.: Modeling Wheat Yield and Crop Water Productivity in Iran: Implications of Agricultural Water Management for Wheat Production, Agr. Water Manage., accepted, doi: 10.1016/j.agwat.2010.07.002, 2010.

Farshi, A. A., Shariati, M. R., JaroLlahi, R., Ghaemi, M. R., Shahabifar, M., and Tavallaei, M. M.: An Estimate of Water Requirement of Main Field Crops and Orchards in Iran, 900 pp., Vol. 1, Ministry of Agriculture, Agricultural and Natural Resource Organization, and Water and Soil Research Institute Press, Karaj, Iran, 1997.

Figueria, J. and Roy, B.: Determining the weights of criteria in the ELECTRE type methods with a revised Simo's procedure, Eur. J. Oper. Res., 139, 317-326, doi:10.1016/S0377-2217(01)00370-8, 2002.

Filizadeh, Y., Rezazadeh, A., and Younessi, Z.: Effects of crop rotation and tillage depth on weed competition and yield of rice in the paddy fields of Northern Iran, J. Agric. Sci. Technol., 9, 99-105, 2007.

Foued, B. A. and Sameh, M.: Application of goal programming in a multi-objective reservoir operation model in Tunisia, Eur. J. Oper. Res., 133, 352-361, doi:10.1016/S0377-2217(00)00303-9, 2001

Ines, A. V. M., Honda, K., Das Gupta, A., Droogers, P., and Clemente, R. S.: Combining remote sensing-simulation modeling and genetic algorithm optimization to explore water management options in irrigated agriculture, Agr. Water Manage., 83, 221-232, doi:10.1016/j.agwat.2005.12.006, 2006.

Kangas, A., Kangas, J., and Pykalainen, J.: Outranking methods as tools in strategic natural resources planning, Silva Fennica, 35, 215-227, 2002

Keshavarz, A., Ashrafi, S., Hydari, N., Pouran, M., and Farzaneh, E.: Water allocation and pricing in agriculture of Iran, in in Water Conservation, Reuse, and Recycling: Proceeding of an Iranian-
American workshop, The National Academies Press: Washington, DC, 153-172, 2005.

Liu, J. and Savenije, H. H. G.: Time to break the silence around virtual-water imports, Nature, 453, 587, 2008.

Liu, J., Zehnder, A. J. B., and Yang, H.: Historical trends in China's virtual water trade, Water Int., 32(1), 78-90, 2007.

Makowski, D., Hendrix, E. M. T., van Ittersum, M. K., and Rossing, W. A. H.: A framework to study nearly optimal solutions of linear programming models developed for agricultural land use exploration, Ecol. Model., 131, 65-77, doi:10.1016/S03043800(00)00249-0, 2000.

Mau-Crimmins, T., de Steiguer, J. E., and Dennis, D.: AHP as a means for improving public participation: a pre-post experiment with university students, Forest Policy and Economics, 7, 501514, doi:10.1016/j.forpol.2003.08.001, 2005.

Mousavi, S. J. and Shourian, M.: Adaptive sequentially space filling meta-modeling for optimal water allocation at basin scale, Water Resour. Res., doi:10.1029/2008WR007076.

Nasiri, M., Niknejad, Y., Pirdashti, H., Barari Tari, D., and Nasiri, S.: Growth, yield and yield traits of rice varieties in rotation with clover, potato, canola, and cabbage in North of Iran, Asian Journal of Plant Sciences, 7, 495-499, 2008.

NCCO: Initial National Communication to United Nations Framework Convention on Climate Change, Published by Iranian $\mathrm{Na}-$ tional Climate Change Office at Department of Environment, Tehran, Iran, 2003.

NRC, National Research Council: Water Conservation, Reuse, and Recycling: Proceedings of an Iranian-American Workshop, Committee on US-Iranian Workshop on Water Conservation and Recycling, The National Academic Press, Washington, DC, 2005.

Pazira, E. and Sadeghzadeh, K.: Sustainable soil and water use in agricultural sector of Iran, in: Proceedings of 99 international conference on agricultural engineering, Beijing, China, II25II32, 1999.

Prato, T. and Herath, G.: Multiple-criteria decision analysis for integrated catchments management, Ecol. Econ., 63, 627-632, doi:10.1016/j.ecolecon.2007.01.003, 2007.

Qadir, M., Sharma, B. R., Bruggeman, A., Choukr-Allah, R., and Karajeh, F.: Non- conventional water resources and opportunities for water augmentation to achieve food security in water scarce countries, Agr. Water Manag., 87, 2-22, doi:10.1016/j.agwat.2006.03.018, 2007.

Qadir, M., Boers, T. M., Schubert, S., Ghafoor, A., and Murtaza, G.: Agricultural water management in water-starved countries: challenges and opportunities, Agr. Water Manag., 62, 165-185, 2003.

Stads, G. J., Roozitalab, M. H., Bientema, N. M., and Aghajani, M.: Agricultural research in Iran: Policy, investments, and institutional profile, International Food Policy Research Institute and Agricultural Extension, Education and Research Organization, 58 pp., 2008.

Wiek, A. and Binder, C.: Solution spaces for decision-making a sustainability assessment tool for city-region, Environ. Impact Assess., 25, 589-608, 2005.

Yang, H., Reichert, P., Abbaspour, K. C., and Zehnder, A. J. B.: A water resources threshold and its implications for food security, Environ. Sci. Technol., 37(14), 3048-3054, doi:10.1021/es0263689, 2003. 
Yang, H. and Abbaspour, K. C.: Analysis of wastewater reuse potential in Beijing, Desalination, 212, 238-250, doi:10.1016/j.desal.2006.10.012, 2007.

Yang, H., Wang, L., Abbaspour, K. C., and Zehnder, A. J. B.: Virtual water trade: an assessment of water use efficiency in the international food trade, Hydrol. Earth Syst. Sci., 10, 443-454, doi:10.5194/hess-10-443-2006, 2006.
Yuan, Z., Zhi-feng, Y., Xi-qin, W.: Methodology to determine regional water demand for instream flow and its application in the Yellow rive basin, J. Environ. Sci., 18(5), 1031-1039, doi:10.1016/S1001-0742(06)60034-X, 2006. 